https://doi.org/10.19195/2450-274X.6.1

\title{
Słowo od redakcji
}

Oddajemy do rąk Czytelników kolejny, szósty numer „Rocznika Europeistycznego". Obecny tom został poświęcony szeroko rozumianym zagadnieniom związanych z tak zwaną europeizacją naszego kontynentu, która jest procesem kształtowania w wymiarze ideowym, globalnym, ale również w postaci zjawisk jednowątkowych i jednowymiarowych - określanych mianem szczegółowych. Kwestie szczegółowe, jak się okazuje, mają istotny wpływ na europeizację Europejczyków. Niekiedy są one w literaturze pomijane czy też niedoceniane. Tym bardziej należy na tym etapie integracji kontynentu zwracać na nie uwagę. Ostatnimi czasy zaczęły one odgrywać coraz większą role w charakterze spójności życia społecznego. Stąd numer szósty ma charakter aktualistyczny i jest on celowym zabiegiem redakcyjnym wynikającym z dążenia do analizy w literaturze naukowej niektórych bieżących problemów społecznych i politycznych. Dlatego będziemy, jako Redakcja, otwarci na akcesję ze strony wszystkich ośrodków europeistycznych i politologicznych w kraju i za granicą. Pismo nasze stopniowo rozwija się w kompleksowe forum wymiany idei, poglądów i wyników badań, które de facto wyczerpują przedmiot zainteresowania europeistyki jako nauki. Europeistyka stała się w pełni równoprawną nauką w stosunku do pozostałych dyscyplin społecznych, pod względem zarówno jakości badań, jak i osiąganych wyników. Zależy nam, aby nasze pismo stało się forum prezentacji wyników badań w zakresie europeistyki również dla politologów, socjologów, kulturoznawców, a nawet filozofów. Nakłada to na redakcję i autorów zobowiązania i troskę o poziom merytoryczny studiów i artykułów. Mamy ambicje, aby periodyk stał się jednym z czynników prezentacji osiągnięć polskiej europeistyki na forum międzynarodowym i inicjatorem wymiany myśli z ośrodkami zagranicznymi.

Przyszłość europeistyki i jej znaczenie w nauce będą zależeć od umiejętności zachowania ciągłości jej rozwoju. Osiągniecia uczonych starszego pokolenia i młodych badaczy, czyli zachowanie ciągłości w badaniach, będzie determinowało rozwój tej ważnej obecnie dziedziny. Pisał o tym między innymi znawca nauk 
społecznych S. Ossowski, podkreślając, iż o rozwoju danej dyscypliny decydują nie tylko badania indywidualne, lecz ciągłość badań i łączenie tego co „stare”, z tym co „nowe” w nauce. Można więc zauważyć, że w kręgu badań europejskich szczególnie mamy do czynienia z pokoleniowymi zmianami. Nowi adepci stają $\mathrm{w}$ obliczu nowych wyzwań, często bez zahamowana i obciążeń przeszłości. Przykładem może być bieżący numer „Rocznika”. W ogóle mamy do czynienia z procesem integracji środowiska europeistów i współpracy pokoleniowej; dobrze wróży to naszej dyscyplinie w czasach obecnych i przyszłości. Zapewne będzie to satysfakcją dla autorów i periodyków europeistycznych.

Zagadnienia, tematy poruszane $\mathrm{w}$ artykułach $\mathrm{z}$ zakresu europeistyki, $\mathrm{z}$ uwagi na zmienny czas i okoliczności ich powstania, a także rozmaitość podmiotów politycznych, które je adaptują, ulegają zróżnicowaniu. Świadczy o tym tematyka poruszana w niniejszym numerze. To zróżnicowanie zainteresowań u europeistów jest jednocześnie względne i nie tylko uwarunkowane sytuacyjnie, ale jest też zależne od procesów społecznych w ich materialnym i świadomościowym wymiarze. W artykułach zawartych w bieżącym numerze istotnym jest, że współczesny wymiar interpretacji został w nich odniesiony do najbardziej aktualnego i najbliższego nam okresu, w którym występują zjawiska społeczne o szerszym i węższych zakresie.

Numer szósty „Rocznika” zawiera cztery artykuły, w tym jeden w języku angielskim, oraz dwie recenzje opracowań monograficznych. Dodatkowo powołaliśmy nowy dział „Aktualności z Parlamentu Europejskiego”. Pragniemy, aby „Rocznik” lepiej odzwierciedlał aktualny stan rozwoju integracji europejskiej i wskazywał obszary budzące szczególne zainteresowanie Unii Europejskiej. W tym celu zwróciliśmy się do eurodeputowanych z rejonu Dolnego Śląska, aby zechcieli publikować na naszych łamach analizy bieżących prac Parlamentu Europejskiego. W niniejszym numerze prezentujemy artykuł Pani Anny Zalewskiej (w wersji polsko- i angielskojęzycznej), licząc na podobne analizy i komentarze w kolejnych numerach naszego periodyku - formułowane przez autorów z rozmaitych stron naszej sceny politycznej.

W tomie zachowano indywidualny charakter tekstów, zgodnie z autorskim ujęciem tematu szczegółowego. Wyrazem poszanowania indywidualnych podejść do problemów badawczych postanowiono zrezygnować z ujednolicenia siatki pojęciowej i kwestii metodologicznych, co urozmaiciło między innymi przekaz naukowy.

Życzymy miłej lektury!

Pawet Turczyński

Redaktor Naczelny

Rafał Juchnowski Sekretarz Redakcji 